\title{
Content pattern Analysis of Selected Parameters in Social Science Post-Graduate Theses
}

\author{
Deinichwa Dkhar ${ }^{1}$ and Allan Thomas ${ }^{2}$
}

\begin{abstract}
In this study, it was aimed to examine the postgraduate theses on Social Science research submitted at College of Agriculture, Vellayani, Kerala during 2012-17 using qualitative content analysis. All the postgraduate theses that could be accessed in the college library were included in the scope of the study. As a result of the research, it was found that 66 post graduate theses under social sciences were conducted at College of Agriculture, Vellayani during 2012-2017. The same was subjected to qualitative content analysis. A total of seven attributes viz., number of words in title, number of words in abstract, number of references in thesis, types of sources of references, research design and statistical methods employed for social science PG research were studied for all departments in social science division.
\end{abstract}

Keywords: Content analysis; social science; extension; postgraduate; research; Kerala

\section{INTRODUCTION}

Agriculture as the cornerstone of Indian economy plays a pivotal role in uplifting the socio-economic realm of the country.

The agrarian research framework in India incorporates around 27,500 scientists and more than one lakh supporting staff effectively engaged with farming examination, which makes it the biggest and institutionally, the most multifaceted research system in the world (Borthakur and Singh, 2012). Newcomb (1993) identified the need to transform university agricultural education programmes and also encouraged a different approach to research in agricultural education to include a defined programme of inquiry.

The agricultural research and education accountabilities at the state level rest with the State Agricultural Universities (SAUs). Kerala Agricultural University (KAU) focuses its strategy on synergizing multidisciplinary education and strengthening problem specific research, relevant to the state and aims at overall development of all agriculture related institutions. Extension research is one of its major components is post-graduation research. Therefore, a study was essential to comprehend the pattern of social science agricultural research that will

1. PG Scholar and 2. Assistant Professor (Sel. Gr.), Department of Agricultural Extension, College of Agriculture (KAU), Vellayani, Thiruvananthapuram- 695522

Received : 16-08-2019; Accepted : 27-09-2019 
enable to identify, scientifically document and publish the contribution of KAU made to the agrarian society through PG Research. Hence, this study on content analysis is of great importance with special reference to analyze the pattern of Post Graduate (PG) social science research studies on its contents and related parameters.

Content analysis, in this study is operationalised as an organized, replicable procedure for analysis of textual documents based on unambiguous rules of coding (Berelson, 1952; Krippendorff, 1980; and Weber, 1990). Holsti (1969) offers a broad definition of content analysis as, "any technique for making inferences by objectively and systematically identifying specified characteristics of messages".

\section{METHODOLOGY}

The study was conducted at College of Agriculture Vellayani campus of Kerala Agricultural University during 2017-2019. The entire theses submitted under social science division (Department of Agricultural Extension, Agricultural Economics and Community Science) from 2012 to 2017 was enumerated and categorized year wise and department wise. Based on the objectives set forth, a qualitative content analysis was followed. A desk study of content pattern was expended for content patterns of post graduate research studies in terms of different attributes viz., number of words in title, number of words in abstract, number of references in thesis, types of sources of references, research design and statistical methods employed for social science PG research. In order to check for significance between disciplines on selected content parameters, an 'open access socscistatistics software' was used to conduct $F$ test- one way analysis of variance (to compare the means of three or more independent samples simultaneously) and $\mathrm{T}$ test (to compare two independent means simultaneously).

\section{FINDINGS AND DISCUSSION}

Content patterns of post graduate research studies in terms of different attributes viz., number of words in title, number of words in abstract and number of references in thesis are illustrated in Table 1.

\section{Number of Words in Title:}

It refers to the distinct meaningful element of writing that constitutes the title of the theses. More than sixty per cent of Agricultural Extension (61.76), Agricultural Economics (66.67) and Community Science (73.91) theses were medium worded with 9-17, 9-15 and 7-15 number of words respectively. However, Agricultural Extension theses topped the list for low ( $<9$ words) worded theses (23.53\%) and Agricultural Economics theses exceeded Agricultural Extension and Community Science with 22.22 per cent of theses being high worded (>15 words). The minimum and maximum number of words was observed in Community Science with 5 and 25 respectively.

\section{Number of Words in Abstract:}

It refers to the number of words in a thesis abstract. Majority of Agricultural 
Table 1

Distribution of theses based on number of words in title, number of words in abstracts and number of references in theses

\begin{tabular}{|c|c|c|c|c|c|c|c|c|c|c|c|}
\hline \multirow[t]{2}{*}{$\begin{array}{l}\text { Sl. } \\
\text { No. }\end{array}$} & \multirow[t]{2}{*}{$\begin{array}{l}\text { Content } \\
\text { pattern }\end{array}$} & & \multicolumn{3}{|c|}{$\begin{array}{l}\text { Agricultural } \\
\text { Extension } \\
(n=34)\end{array}$} & \multicolumn{3}{|c|}{$\begin{array}{l}\text { Agricultural } \\
\text { Economics } \\
\quad(n=9)\end{array}$} & \multicolumn{3}{|c|}{$\begin{array}{c}\text { Community } \\
\text { Science } \\
(n=23)\end{array}$} \\
\hline & & & $\mathrm{H}$ & $M$ & $\mathrm{~L}$ & $\mathrm{H}$ & $M$ & $\mathrm{~L}$ & $\mathrm{H}$ & $M$ & $\mathrm{~L}$ \\
\hline \multirow{5}{*}{1.} & \multirow{4}{*}{$\begin{array}{l}\text { Number of } \\
\text { words in title }\end{array}$} & $\begin{array}{l}\text { Class } \\
\text { limits }\end{array}$ & $>17$ & $9-17$ & $<9$ & $>15$ & $9-15$ & $<9$ & $>15$ & $7-15$ & $<7$ \\
\hline & & $f$ & 5 & 21 & 8 & 2 & 6 & 1 & 4 & 17 & 2 \\
\hline & & $\%$ & 14.71 & 61.76 & 23.53 & 22.22 & 66.67 & 11.11 & 17.39 & 73.91 & 8.7 \\
\hline & & & \multicolumn{3}{|c|}{$\begin{array}{c}\text { Mean=12.82;SD= } \\
4.2 \\
\text { Min-Max=6-22 }\end{array}$} & \multicolumn{3}{|c|}{$\begin{array}{c}\text { Mean=11.78;SD= } \\
\text { 3.19; Min-Max=8-17 }\end{array}$} & \multicolumn{3}{|c|}{$\begin{array}{c}\text { Mean=11.09;SD= } \\
\text { 4.37; } \\
\text { Min-Max=5-25 }\end{array}$} \\
\hline & $\begin{array}{l}\text { One way } \\
\text { anova }\end{array}$ & \multicolumn{10}{|c|}{$\begin{array}{l}\text { The } \mathrm{f} \text {-ratio value is } 0.2785 \text {. The } p \text {-value is }<.758063 \text {; The result is not significant } \\
\qquad \text { at } p<.01 \text { and } p<.05\end{array}$} \\
\hline \multirow{5}{*}{2.} & \multirow{4}{*}{$\begin{array}{l}\text { Number of } \\
\text { words in an } \\
\text { abstract }\end{array}$} & $\begin{array}{l}\text { Class } \\
\text { limits }\end{array}$ & $>710$ & $\begin{array}{l}382- \\
710\end{array}$ & $<382$ & $>803$ & $\begin{array}{l}489- \\
803\end{array}$ & $<489$ & $>700$ & $\begin{array}{l}400- \\
700\end{array}$ & $<400$ \\
\hline & & $f$ & 4 & 24 & 6 & 2 & 6 & 1 & 2 & 18 & 3 \\
\hline & & $\%$ & 11.76 & 70.59 & 17.65 & 22.22 & 66.67 & 11.11 & 12.12 & 72.73 & 15.15 \\
\hline & & & \multicolumn{3}{|c|}{$\begin{array}{c}\text { Mean=546.47; } \\
\text { SD=164.15 } \\
\text { Min-Max=341-984 }\end{array}$} & \multicolumn{3}{|c|}{$\begin{array}{c}\text { Mean=646; } \\
\text { SD=156.73 } \\
\text { Min-Max=351-872 }\end{array}$} & \multicolumn{3}{|c|}{$\begin{array}{c}\text { Mean=549.91; } \\
\text { SD=149.81 } \\
\text { Min-Max=282-880 }\end{array}$} \\
\hline & $\begin{array}{l}\text { One way } \\
\text { anova }\end{array}$ & \multicolumn{10}{|c|}{$\begin{array}{l}\text { The } \mathrm{f} \text {-ratio value is 1.49631. The } p \text {-value is }<.231806 \text {; The result is not significant } \\
\qquad \text { at } p<.01 \text { and } p<.05\end{array}$} \\
\hline \multirow{4}{*}{3} & \multirow{4}{*}{$\begin{array}{l}\text { Number of } \\
\text { references in } \\
\text { thesis }\end{array}$} & $\begin{array}{l}\text { Class } \\
\text { limits }\end{array}$ & $>162$ & $\begin{array}{l}78- \\
162\end{array}$ & $<78$ & $>106$ & $\begin{array}{l}79- \\
106\end{array}$ & $<79$ & $>284$ & $\begin{array}{l}130- \\
284\end{array}$ & $<130$ \\
\hline & & $f$ & 5 & 24 & 5 & 1 & 7 & 1 & 1 & 20 & 2 \\
\hline & & $\%$ & 14.71 & 70.58 & 14.71 & 11.11 & 77.78 & 11.11 & 4.35 & 86.96 & 8.69 \\
\hline & & & \multicolumn{3}{|c|}{$\begin{array}{c}\text { Mean=117.47; } \\
\text { SD=44.59 } \\
\text { Min-Max=51-245 }\end{array}$} & \multicolumn{3}{|c|}{$\begin{array}{c}\text { Mean=92.78; } \\
\text { SD=13.59 } \\
\text { Min-Max=69-116 }\end{array}$} & \multicolumn{3}{|c|}{$\begin{array}{c}\text { Mean=206.65; } \\
\text { SD=77.03 } \\
\text { Min-Max=87-477 }\end{array}$} \\
\hline & $\begin{array}{l}\text { One way } \\
\text { anova }\end{array}$ & \multicolumn{10}{|c|}{$\begin{array}{l}\text { The } f \text {-ratio value is } 20.94061 \text { The } p \text {-value is }<.00001 \text {; The result is } \\
\text { significant at } p<.01 \text { and } p<.05\end{array}$} \\
\hline
\end{tabular}

H-High, M-Medium, L-Low, SD-Standard deviation. 
Content pattern Analysis of Selected Parameters in Social Science Post-Graduate Theses

Extension (70.59), Agricultural Economics (66.67), and Community Science (72.73\%) theses were medium worded i.e. 382-710, 489-803 and 400-700 words respectively. However, Agricultural Extension theses topped (23.53\%) the list for low worded theses (<382 words) and Agricultural Economics theses surpassed Agricultural Extension and Community Science with 22.22 per cent of theses being high worded (>803 words). The minimum (282) and maximum (984) number of words were from Community Science and Agricultural Extension respectively.

Even though there is no fixed limit prescribing number of words in a title for research, care should be taken to use fewer words yet descriptive enough to depict the research scope. Cherry (2019) specified that the number of words in the title according to APA (American Psychological Association) style (6 $6^{\text {th }}$ edition) should not be more that 12 words and for an abstract the number of words should be between 150 and 250 words.

\section{Number of References in Thesis:}

References here refer to the list of all the sources from which the researchers obtained information for their research work and it is represented in the last page of the thesis. Majority (70.58, 77.78 and 86.96\%) of Agricultural Extension, Agricultural Economics and Community Science theses were having medium number of references i.e. 78-162, 79-106 and 130-284 references respectively. However, Agricultural Extension theses topped the list for both high $(>162$ references) and low ( $<78$ references) category and surpassed Agricultural Economics and
Community Science theses with 14.71 per cent in each category. The minimum (51) and maximum (477) of number of references were observed in Agricultural Extension and Community Science respectively.

Distribution of theses based on number of words in title, number of words in abstracts and number of references in theses for the three disciplines of PG study was subjected to $f$ - test: one way analysis of variance (to compare the means of content parameter for the three disciplines simultaneously). It was found that there was a significant difference for the content parameter viz., number of references in the theses for the three different disciplines at $1 \%$ significance level. It was observed that the $f$-ratio value was 20.94061 and the $p$-value was $<0.00001$ indicating that there was significant difference. The difference could be attributed due to the varying number of references included in each theses by the Post Graduate scholar which was evident from the wide minimum to maximum means as indicated in Table 1. A perusal of discussion forums available online indicates that there is no specific prescribed minimum or maximum numbers of references required for a theses to reflect upon its quality. 'Quality over quantity' should be the focus of including references and it should help the researcher to derive fruitful discussions on results. However no significant differences (both at $1 \%$ and $5 \%$ level of significance) were observed for content parameters such as number of words in title of theses and the number of words in the abstract of theses across the three disciplines of study 
Distribution of Social science theses based on years and types of sources

\section{References based on years}

The social science PG theses are enumerated and classified based on years and types of sources and its results are presented in Table 2 and Table 3.

\section{Table 2}

Distribution of References based on years

\begin{tabular}{|l|c|c|}
\hline \multirow{2}{*}{\multicolumn{1}{|c|}{ Category }} & \multicolumn{2}{c|}{ Social science $\mathbf{N}=66)$} \\
\cline { 2 - 3 } & $\mathbf{f}$ & $\%$ \\
\hline Up to 1900 & 0 & 0.00 \\
\hline $1901-1925$ & 2 & 0.02 \\
\hline $1926-1950$ & 24 & 0.25 \\
\hline $1951-1975$ & 301 & 3.14 \\
\hline $1976-2000$ & 2671 & 27.88 \\
\hline 2001 and after & 6581 & 68.70 \\
\hline Total & 9579 & 100 \\
\hline
\end{tabular}

Reference based on years, in this study is operationalized as the date in which the sources of references were published. Table 2 reveals that 68.70 per cent of the references were from publications made after 2001 followed by 27.88 per cent from 1976-2000 and 2.14 per cent from 1951-1975. A negligible percentage was taken from 1901-1950 indicating the probing habit of the researchers. This could be due to the fact that students might resort to the practice of searching the previous theses published recently or the wide variety of online journals that are available to the students for referencing.

\section{TYPES OF SOURCES OF REFERENCES}

Sources of references refer to the different sources such as print materials, online or offline sources the researchers come across while writing his/her thesis. The results are presented in Table 3.

\section{Table 3}

Distribution of References in PG theses based on their sources

\begin{tabular}{|l|l|l|l|}
\hline \multirow{2}{*}{$\begin{array}{c}\text { SI. } \\
\text { No. }\end{array}$} & \multirow{2}{*}{ Types of sources } & \multicolumn{2}{|c|}{$\begin{array}{c}\text { Social science } \\
(\mathbf{N}=66)\end{array}$} \\
\cline { 3 - 4 } & & $\mathbf{f}$ & \multicolumn{1}{|c|}{$\%$} \\
\hline 1 & Books & 1344 & 14.03 \\
\hline 2 & Journals & 5330 & 55.64 \\
\hline 3 & Thesis & 1467 & 15.31 \\
\hline 4 & Reports & 176 & 1.84 \\
\hline 5 & $\begin{array}{l}\text { Seminar/ } \\
\text { Conferences }\end{array}$ & 324 & 3.38 \\
\hline 6 & Magazines & 83 & 0.87 \\
\hline 7 & Newspapers & 49 & 0.51 \\
\hline 8 & Online sources-URL & 493 & 5.15 \\
\hline 9 & Others & 313 & 3.27 \\
\hline
\end{tabular}

From the Table 3 it can be seen that 55.64 per cent of the references were from journals followed by 15.31 per cent from thesis, 14.03 per cent from books, 5.15 per cent from online sources with URL, 3.38 per cent from seminar/ conferences, 3.27 per cent from other sources and 1.81, 0.87 and 0.51 per cent from reports, magazines and newspapers respectively.

Many discussions on online platforms of research like 'Research Gate' suggest different views on the number and types of references based on sources. Publishers of eminence like Sage and Elsevier have set as a general rule that one source per page average i.e., a paper that has 20 manuscript pages might have about 20 sources. Some researchers are of 
Content pattern Analysis of Selected Parameters in Social Science Post-Graduate Theses

the view that saturation point of ideas should be the basis of citing references. However, many of such opinion converge to the view that it should have 'quality over quantity' of references that matter in terms of number and sources. The researcher should learn how to integrate the literature based on the analytical and/or synthetical process of research.

\section{Research Design}

Research design refers to the set of procedure or methods used in collecting and analyzing measures of variables on the research problem and the results are presented in Table 4.

From Table 4 , it is clear that almost fifty per cent $(49.28 \%)$ of the theses in Agricultural Extension department used ex post facto designs and 4.35 per cent used exploratory design. Only, 1.45 per cent of Community Science theses used CRD
(Completely Randomized Design) and factorial CRD respectively.

Social science researchers focus main by on incidents that have already occurred research which might be the reason for majority of the researchers using expost facto design.

\section{Statistical methods}

Statistical methods refer to the different statistical tools that were used for the data analysis for drawing meaningful interpretation of data so as to avail valid information from the study. The results are presented in Table 5.

In agricultural Extension, 25.00 per cent of the theses had used percentage analysis followed by correlation (24.27\%), mean (18.38\%), quartiles (10.29\%), frequency and standard deviation (5.88\%), others (5.15\%), ANOVA (4.41\%) and regressions

Table 4

Classification of Social science theses based on Research design used

\begin{tabular}{|c|c|c|c|c|c|c|c|c|c|}
\hline \multirow[t]{2}{*}{$\begin{array}{l}\text { Sl. } \\
\text { No. }\end{array}$} & \multirow[t]{2}{*}{$\begin{array}{c}\text { Types of } \\
\text { design }\end{array}$} & \multicolumn{2}{|c|}{$\begin{array}{c}\text { Agricultural } \\
\text { Extension }(n=34)\end{array}$} & \multicolumn{2}{|c|}{$\begin{array}{c}\text { Agricultural } \\
\text { Economics }(n=9)\end{array}$} & \multicolumn{2}{|c|}{$\begin{array}{c}\text { Community } \\
\text { Science } \\
(n=23)\end{array}$} & \multicolumn{2}{|c|}{$\begin{array}{l}\text { Total } \\
(\mathrm{N}=66)\end{array}$} \\
\hline & & $f$ & $\%$ & $f$ & $\%$ & $f$ & $\%$ & $f$ & $\%$ \\
\hline 1 & Ex post facto & 34 & 91.89 & 0 & 0.00 & 0 & 0.00 & 34 & 49.28 \\
\hline 2 & Explorative & 3 & 8.11 & 0 & 0.00 & 0 & 0.00 & 3 & 4.35 \\
\hline 3 & CRD & 0 & 0.00 & 0 & 0.00 & 1 & 4.35 & 1 & 1.45 \\
\hline 4 & Factorial-CRD & 0 & 0.00 & 0 & 0.00 & 1 & 4.35 & 1 & 1.45 \\
\hline 5 & Not mentioned & 0 & 0.00 & 9 & $100^{*}$ & 21 & 91.30 & 30 & 43.48 \\
\hline & Total & 37 & 100 & 9 & 100 & 23 & 100 & 69 & 100 \\
\hline
\end{tabular}

* concentrated on Financial appraisal studies in the case of Agricultural Economics- with calculation such as B:C; NPV; IRR and SA- Sensitivity Analysis 
Table 5

Distribution of Statistical methods used in Social science Theses

\begin{tabular}{|c|c|c|c|c|c|c|c|c|c|}
\hline \multirow[t]{2}{*}{$\begin{array}{l}\text { Sl. } \\
\text { No. }\end{array}$} & \multirow[t]{2}{*}{$\begin{array}{l}\text { Statistical } \\
\text { methods }\end{array}$} & \multicolumn{2}{|c|}{$\begin{array}{c}\text { Agricultural } \\
\text { Extension } \\
(n=34)\end{array}$} & \multicolumn{2}{|c|}{$\begin{array}{l}\text { Agricultural } \\
\text { Economics } \\
\qquad(n=9)\end{array}$} & \multicolumn{2}{|c|}{$\begin{array}{l}\text { Community } \\
\text { science } \\
(n=23)\end{array}$} & \multicolumn{2}{|c|}{$\begin{array}{c}\text { Total } \\
(\mathrm{N}=66)\end{array}$} \\
\hline & & $f$ & $\%$ & $f$ & $\%$ & $f$ & $\%$ & $f$ & $\%$ \\
\hline 1 & ANOVA & 6 & 4.41 & 0 & 0.00 & 19 & 37.26 & 25 & 12.76 \\
\hline 2 & Correlation & 33 & 24.27 & 0 & 0.00 & 0 & 0.00 & 33 & 16.84 \\
\hline 3 & Frequency & 8 & 5.88 & 0 & 0.00 & 1 & 1.96 & 9 & 4.59 \\
\hline 4 & Mean & 25 & 18.38 & 0 & 0.00 & 8 & 15.69 & 33 & 16.84 \\
\hline 5 & Percentage & 34 & 25.00 & 0 & 0.00 & 6 & 11.77 & 40 & 20.41 \\
\hline 6 & Quartiles & 14 & 10.29 & 0 & 0.00 & 0 & 0.00 & 14 & 7.14 \\
\hline 7 & Range test & 0 & 0.00 & 0 & 0.00 & 1 & 1.96 & 1 & 0.51 \\
\hline 8 & Regression & 1 & 0.74 & 0 & 0.00 & 1 & 1.96 & 2 & 1.02 \\
\hline 9 & $\begin{array}{l}\mathrm{S} t \text { a } \mathrm{n} \text { d a } \mathrm{r} d \\
\text { deviation }\end{array}$ & 8 & 5.88 & 0 & 0.00 & 0 & 0.00 & 8 & 4.08 \\
\hline 10 & Not mentioned & 0 & 0.00 & 9 & 100.00 & 0 & 0.00 & 9 & 4.59 \\
\hline \multirow[t]{3}{*}{11} & Others & 7 & 5.15 & 0 & 0.00 & 15 & 29.41 & 22 & 11.22 \\
\hline & Total & 136 & 100 & 9 & 100 & 51 & 100 & 196 & 100 \\
\hline & t-test & \multicolumn{8}{|c|}{$\begin{array}{l}t \text {-value was } 1.78949 \text { and the } p \text {-value was } 0.044345 \text { indicating that the } \\
\text { result was significant at } p<.05 \text { but not significant at } p<.01\end{array}$} \\
\hline
\end{tabular}

* concentrated on Financial appraisal studies in case of Agricultural Economics- with calculation such as B:C; NPV; IRR and SA- Sensitivity Analysis

** concentrated on specific empirical measures on qualitative parameters for the processing component included in the study in case of Community Science

(0.74\%). In Agricultural Economics all the theses did not mention any statistical method. In Community Science department 37.26 per cent of the theses used ANOVA followed by 29.41 per cent that used other methods, 15.69 per cent had used mean, 11.77 per cent used percentage and 1.96 per cent used frequency, regressions and range test. The results indicate that the PG researches undertaken by students are subjected to rigorous analysis through confirmed and sound statistical measures.

A 't-test' was conducted to know whether there was any significant difference on the statistical methods used for disciplines viz., Agricultural Extension and Community Science. Theses from the department of Agricultural Economics was not considered 
Content pattern Analysis of Selected Parameters in Social Science Post-Graduate Theses

as all the theses employed Financial Appraisal components with calculation such as B:C; NPV; IRR and SA- Sensitivity Analysis. The results of the t-test revealed that the $\mathrm{t}$-value was 1.78949 and the $p$ value was 0.044345 indicating that the result was significant at $p$ $<.05$. However the result was not significant at $\mathrm{p}<.01$. The significance attributed at 5 $\%$ level of significance could be due to the uniqueness of subject wherein Agricultural Extension theses focus majorly on technosocio-economic aspects and psychological constructs of respondents unlike Community Science theses that also widely incorporates components related to processing aspects in each of their studies.

\section{CONCLUSION}

The outcome of this study shows that majority of the theses in social science division have medium number of words in title as well as in abstract of thesis. More than seventy per cent of the theses have medium number of references, with class limits diverse for different departments. However, more references were from publications made after 2001. Ex-post facto design is the most commonly used research design in Agricultural Extension theses and CRD for Community Science theses. Percentage analysis followed by correlation, mean, quartiles, frequency and standard deviation were the most used statistical tools. The study throws light to the importance of considering the parameters to be generalized and applied for enabling the quality of further research undertaken by the PG scholars of State Agricultural Universities.

\section{REFERENCES}

Berelson, B. (1952).Content analysis in communication research. Free Press. New York, 220p.

Borthakur, A. \& Singh, P. (2012). Agricultural research in India: an exploratory study. International Journal of Social Science Interdisciplinary Research. 1(9):59-74.

Cherry, K. (2019). How to write an APA abstract: tips for creating an abstract in APA style [on-line].Retrieved from :https:// www.verywellmind.com/how-to-write-anabstract-2794845\#citation-1[22 March 2019].

Holsti, O. R. (1969). Content Analysis for the Social Sciences and Humanities.AddisonWesley, Reading, Massachusetts, 256p.

Krippendorf, K. (1980). Content analysis: an introduction to its methodology. Sage Publications, Beverly Hills, California, 441p

Newcomb, L.H. (1993). Transforming university programs of agricultural education. Journal of Agricultural Educaiton. 34(1): 1-10.

Weber, R. P. (1990). Basic Content Analysis. Sage University Paper Series on Quantitative Applications in the Social Sciences, Series no. 07-049. Sage Publications, California, 97p. 